\title{
Evaluation of Genetic Variability and Identification of Micronutrients Rich Recombinant Inbred Lines in Mungbean [Vigna radiata (L.) Wilczek]
}

\author{
Kritika, Rajesh Yadav, Sunayana ${ }^{*}$ and Ravika \\ Pulses Section, Department of Genetics and Plant Breeding, CCS Haryana Agricultural \\ University, Hisar-125 004, India \\ *Corresponding author
}

\begin{tabular}{|l|}
\hline Ke y w o r d s \\
$\begin{array}{l}\text { Genetic variability, } \\
\text { Micronutrients, } \\
\text { Mungbean, Recombinant } \\
\text { Inbred Lines }\end{array}$ \\
\hline Article Info \\
\hline $\begin{array}{l}\text { Accepted: } \\
\text { 04 May } 2018 \\
\text { Available Online: } \\
\text { 10 June } 2018\end{array}$ \\
\hline
\end{tabular}

A B S T R A C T
An investigation was carried out to assess the genetic variability among 70 mungbean Recombinant Inbred Lines (RILs) grown in untreated and treated $\left(\mathrm{ZnSO}_{4}\right.$ and $\left.\mathrm{FeSO}_{4}\right)$ environments and to identify high micronutrient ( $\mathrm{Zn}$ and $\mathrm{Fe}$ ) content RILs. Significant variability among the genotypes was observed for all the characters i.e., days to $50 \%$ flowering and maturity, plant height, number of branches, number of pods, number of seeds per pod, 100-seed weight, seed and biological yield per plot, reaction to MYMV, zinc and iron content in seeds except harvest index. High estimates of GCV, heritability and genetic advance in both the environments for number of branches, seed and biological yield, reaction to MYMV, zinc and iron content in seeds suggested that these characters are controlled by additive gene action. Low GCV coupled with low heritability and low genetic advance observed for number of seeds per pod and harvest index indicated presence of non-additive gene action and high GxE interaction. About $43 \%$ of the RILs responded positively to zinc, $71 \%$ to iron and $29 \%$ to both zinc and iron application. RILs having high zinc and iron contents responded less to their application as compared to those having low to moderate zinc and iron content. RIL-1, 11, 34, 37, 59, 61 and 70 were found to have significantly higher zinc content, RIL-1, 3, 7, 34, and 38 had significantly higher iron and RIL-25, 27, 54, 58, 60 and 67 had higher seed yield.

\section{Introduction}

Vigna radiata (L.) Wilczek, commonly known as mungbean or greengram, is the fourth most important pulse crop of India after chick pea, pigeon pea and black gram and is grown throughout the year in all the three crop seasons in different regions of India. The annual production of mungbean is about 1.5 million tonnes from an area of about 3.02 million hectares in India (Anonymous, 2016). Being a short duration pulse crop it fits well in many cropping systems including the intensive rice-wheat cropping system of IndoGangetic plains of India.

It can also be grown as intercrop with sugarcane, pigeon pea, castor, maize, poplar and in orchards. It is an excellent source of dietary protein of low flatulence which complements the staple wheat and rice diet in Asia and it represents a cheap source of carbohydrates, folate and iron besides highquality protein. 
Micronutrient malnutrition is recognized as a massive and rapidly growing public health issue especially among the poor people. Micronutrient malnutrition causes several diseases and the affected people are more prone to infection by other diseases resulting in further deterioration in quality of life. Zinc and iron are among the most important micronutrients which are required to maintain metabolic regulation and organ function. Zinc acts as a stabilizer of the structures of cellular membranes and components and plays a major role in gene expression.

Its deficiency in humans reduces growth, sexual maturity and immune defence system. Iron is needed for the synthesis of oxygen transport proteins haemoglobin and myoglobin, for the formation of haeme enzymes and other iron containing enzymes responsible for energy production, immune defence and thyroid function and its deficiency in the body causes anaemia. Both zinc and iron are, therefore, essential to human well-being (Singh et al., 2013).

Increasing the amount of micronutrients in plant foods for human consumption is a challenge which is important particularly for a country like India where the population mostly consumes vegetarian food. Study of inheritance of these traits through estimation of different genetic parameters could be helpful in formulation of an effective breeding programme. Considerable amount of knowledge has been generated during last two decades with regards to yield and component traits; however, very few studies have been conducted to access these parameters for micronutrients content in mungbean seed. Therefore, the present investigation was undertaken with an objective to assess the genetic parameters like variability, heritability, genetic advance and seed micronutrients ( $\mathrm{Zn}$ $\& \mathrm{Fe})$ content in Recombinant Inbred Lines (RILs) of mungbean.

\section{Materials and Methods}

This field experiment was carried out in kharif 2015 at the Pulses Research Area of Department of Genetics and Plant Breeding and zinc and iron content in soil and seed samples were estimated in the laboratory of Department of Soil Sciences, Chaudhary Charan Singh Haryana Agricultural University, Hisar. The experimental material for the present investigation comprised of 70 mungbean RILs in $\mathrm{F}_{6}$ generation, their two parents (ML 776 and $\mathrm{MH}$ 2-15) and three popular cultivated varieties of mungbean as yield checks (MH 1-25, MH 421 and $\mathrm{MH}$ 318). Mungbean genotype ML 776 is having high zinc and iron content in seeds and $\mathrm{MH} 2-$ 15 is a high yielding MYMV resistant released variety of mungbean which has low zinc and iron content (Taunk et al., 2012). The experiment was conducted in two sets, untreated one with Recommended Doses of Fertilizer (RDF) only and treated one with $\mathrm{RDF}+25 \mathrm{~kg} / \mathrm{ha} \mathrm{ZnSO}_{4}$ as basal dose and $0.5 \%$ solution of $\mathrm{FeSO}_{4}$ as foliar spray at flowering stage. Both the sets of the experiment were laid out in Randomized Block Design (RBD) with three replications. All the genotypes were grown in a plot size of 2 rows $\times 2 \mathrm{~m}$. The row to row distance was kept $30 \mathrm{~cm}$ and plant to plant distance $10 \mathrm{~cm}$.

The observations were recorded as the means from five randomly selected plants from each genotype in each replication for plant height, number of branches per plant, number of pods per plant and number of seeds per pod. Other traits viz., days to $50 \%$ flowering, days to maturity, 100-seed weight, seed yield per plot, biological yield per plot, harvest index, reaction to Mungbean Yellow Mosaic Virus (MYMV) were determined on plot basis. For recording incidence of MYMV, 1 to 9 ratings scale was used (Anonymous, 2016). Atomic Absorption Spectrophotometer (AAS) analysis of Benton-Jones (1989) based on 
nitric/perchloric acid digestion was followed to estimate the zinc and iron concentration in mungbean seeds of all the genotypes.

The data collected for each quantitative trait mentioned above were subjected to analysis of variance. The phenotypic and genotypic variances and their coefficients were estimated according to the methods suggested by Burton and Devane (1953), whereas estimation of heritability and estimation of expected genetic advance were computed using the formula suggested by Hanson et al., (1956) and Johnson et al., (1955), respectively.

\section{Results and Discussion}

The knowledge of nature and extent of genetic variability for various characters are essential in planning the breeding strategies. Analysis of variance of both the environments indicated that mean squares due to genotypes were significant for all the characters studied viz. days to $50 \%$ flowering, days to maturity, plant height, number of branches per plant, number of pods per plant, number of seeds per pod, 100-seed weight, seed yield per plot, biological yield per plot, reaction to MYMV, zinc and iron content in seeds except harvest index revealing thereby presence of considerable amount of variability among the RILs of mungbean for all the characters. Similar findings were reported by Khedar et al., (2006), Arshad et al., (2009), Tabasum et al., (2010), Rathor et al., (2015) and Om Vir and Singh (2016) in mungbean for various traits.

All these characters were compared for their performance under untreated and treated environments using Independent t-test (at $\mathrm{p}<$ 0.05 significance) which revealed that plant height, number of branches per plant, 100seed weight, seed yield per plot, biological yield per plot, zinc and iron content in seeds were the traits which were affected by the application of zinc and iron. Our findings are in partial confirmation of the previous studies of Samreen et al., (2013) and Singh et al., (2013).

Phenotypic (PCV) and genotypic (GCV) coefficients of variation were worked out for all the traits studied to make further assessment of heritable and non-heritable components in the total variability observed. The GCV and PCV were categorized as low $(<10 \%)$, moderate $(11-20 \%)$ and high $(>20$ $\%)$ as suggested by Shivasubramanian and Menon (1973). Narrow to medium differences between the genotypic and phenotypic coefficients of variation for different traits under both the environments (Table 1) indicated low to moderate influence of environment in the expression of these traits. The range of PCV for different traits was observed from 4.59 (days to maturity) to 54.52 $\%$ (iron content) and from 4.46 (days to maturity) to $39.09 \%$ (reaction to MYMV) under untreated and treated environments, respectively, whereas the range of GCV was 3.91 (days to maturity) to $45.58 \%$ (iron content) and from 3.67 (days to maturity) to $35.04 \%$ (reaction to MYMV) under untreated and treated environments, respectively. The presence of wide range of PCV and GCV revealed the larger extent of phenotypic and genetic variability.

High PCV was observed for iron content, reaction to MYMV, zinc content, seed yield per plot, biological yield per plot, number of pods per plant and number of branches per plant, whereas harvest index, number of seeds per pod and plant height exhibited moderate PCV and 100-seed weight, days to $50 \%$ flowering and days to maturity exhibited low PCV under both untreated and treated environments. High magnitude of GCV was observed for iron content, reaction to MYMV, zinc content, seed yield per plot, biological yield per plot, number of branches per plant 
under both untreated and treated environments and number of pods per plant only under untreated environment, however, characters viz. harvest index, plant height and number of seeds per pod depicted moderate GCV and 100 -seed weight, days to $50 \%$ flowering and days to maturity had low GCV under both untreated and treated environments. These observations are relatable to the findings of Gadakh et al., (2013), Jyothsna and Anuradha (2013) and Niharika et al., (2014). Characters like days to $50 \%$ flowering, days to maturity, plant height, number of seeds per pod, 100seed weight and harvest index have shown low to moderate GCV and PCV which signifies lesser likelihood of much improvement through selection in these traits. These results are in agreement with the findings of Khedar et al., (2006) and Rathor et al., (2015) but show disagreement to the findings of Dhananjay et al., (2009) and Tiwari et al., (2014).

Heritability (broad sense) and genetic advance estimates for different traits were computed to find out the extent of heritable nature of variability and expected genetic gain under selection. Heritability estimates were grouped as low $(<30 \%)$, moderate $(30-60 \%)$ and high $(>60 \%)$ and genetic advance as per cent of mean as low $(<10 \%)$, moderate $(10-20 \%)$ and high (> $20 \%$ ) as suggested by Johnson $e t$ al., (1955). Heritability (broad sense) under untreated environment ranged from 40.55 to $83.23 \%$ and under treated environment 48.53 to $81.40 \%$. Genetic advance as per cent of mean ranged from 6.88 to $65.53 \%$ and 6.22 to $64.70 \%$ under untreated and treated environments, respectively.

High heritability estimates coupled with high genetic advance were recorded for plant height, number of branches per plant, number of pods per plant, seed and biological yield per plot, reaction to MYMV, zinc and iron content in seeds. The high heritability and genetic advance estimates are pleasant indication for the success in selection. This indicated the predominance of additive gene action in the expression of all the listed traits and these traits are likely to respond effectively to phenotypic selection (Johnson et al., 1955). Cognate results were obtained by Arshad et al., (2009), Suresh et al., (2010), Reddy et al., (2011), Prakash and Shekhawat (2012), Gadakh et al., (2013), Singh et al., (2014) and Kumar and Katiyar (2015) but different results were obtained by Begum et al., (2012) and Niharika et al., (2014). Low to moderate heritability and genetic advance estimates were observed for number of seeds per pod and harvest index which indicated that these characters are influenced by environment and can be improved by rigorous selections in large segregating populations, especially early generations. Tabasum et al., (2010) and Begum et al., (2012) obtained analogous results for these characters while, Gadakh et al., (2013), Jyothsna and Anuradha (2013) and Tiwari et al., (2014) obtained dissimilar ones.

Genotypic coefficient of variation together with heritability estimates would give the best indication of the amount of gain due to selection. Number of branches per plant, seed and biological yield per plot, reaction to MYMV, zinc and iron content in seeds had high GCV and corresponding heritability and genetic advance. This conveys that these characters are genetically controlled by additive gene action and can be improved through selection. Arshad et al., (2009), Gadakh et al., (2013) and Raturi et al., (2015) found similar results while Dhananjay et al., (2009) and Tabasum et al., (2010) reported conflicting results for these traits. Number of seeds per pod and harvest index exhibited low GCV and low heritability coupled with low genetic advance. This grants a point that these characters are governed by non-additive gene action and there is high genotype and environment interaction. 
Table.1 Estimates for mean, range, GCV, PCV, heritability and genetic advance for different characters in mungbean RILs under untreated and treated environments

\begin{tabular}{|c|c|c|c|c|c|c|c|c|c|c|c|c|}
\hline \multirow[t]{2}{*}{ Characters } & \multicolumn{2}{|c|}{ Mean } & \multicolumn{2}{|c|}{ Range } & \multicolumn{2}{|c|}{ GCV (\%) } & \multicolumn{2}{|c|}{ PCV (\%) } & \multicolumn{2}{|c|}{$\begin{array}{c}\text { Broad sense } \\
\text { heritability } \\
(\%)\end{array}$} & \multicolumn{2}{|c|}{$\begin{array}{c}\text { Genetic } \\
\text { advance } \\
\text { as } \% \text { of mean }\end{array}$} \\
\hline & UT & $\mathbf{T}$ & UT & $\mathbf{T}$ & UT & $\mathbf{T}$ & UT & $\mathbf{T}$ & UT & $\mathbf{T}$ & UT & $\mathbf{T}$ \\
\hline $\begin{array}{l}\text { Days to } 50 \% \\
\text { flowering }\end{array}$ & 35.0 & 34.7 & $30.3-40.3$ & $30.3-40.0$ & 7.00 & 6.53 & 7.75 & 7.35 & 81.66 & 78.90 & 13.03 & 11.96 \\
\hline $\begin{array}{l}\text { Days to } \\
\text { maturity }\end{array}$ & 58.9 & 58.3 & $53.7-62.3$ & $53-61.3$ & 3.91 & 3.67 & 4.59 & 4.46 & 72.87 & 67.70 & 6.88 & 6.22 \\
\hline Plant height (cm) & 40.6 & 42.2 & $28.4-49.5$ & $28.6-52.4$ & 11.55 & 11.27 & 13.13 & 12.64 & 77.46 & 79.50 & 20.94 & 20.71 \\
\hline $\begin{array}{l}\text { No. of branches per } \\
\text { plant }\end{array}$ & 3.0 & 3.2 & $1.8-4.4$ & $2.0-4.8$ & 21.09 & 22.74 & 24.13 & 25.21 & 76.44 & 81.40 & 37.99 & 42.26 \\
\hline $\begin{array}{l}\text { Number of pods } \\
\text { per plant }\end{array}$ & 10.9 & 11.1 & $6-15.7$ & $6-15$ & 20.86 & 19.74 & 25.96 & 22.32 & 64.61 & 78.20 & 34.55 & 35.96 \\
\hline $\begin{array}{l}\text { Number of seeds } \\
\text { per pod }\end{array}$ & 7.5 & 7.6 & $5.7-10$ & $6-10.3$ & 11.08 & 11.57 & 15.33 & 15.21 & 52.26 & 57.80 & 16.49 & 18.13 \\
\hline $\begin{array}{l}\text { 100-seed weight } \\
\text { (g) }\end{array}$ & 3.50 & 3.66 & $3.08-4.63$ & $3.15-4.66$ & 8.78 & 8.44 & 9.62 & 9.45 & 83.23 & 79.90 & 16.49 & 15.55 \\
\hline $\begin{array}{l}\text { Seed yield per plot } \\
\text { (g) }\end{array}$ & 83.9 & 90.8 & $46.5-138.3$ & 48.6-146.7 & 23.85 & 23.79 & 29.74 & 28.02 & 64.35 & 72.15 & 39.20 & 38.94 \\
\hline $\begin{array}{l}\text { Biological yield per } \\
\text { plot }(\mathrm{g})\end{array}$ & 501 & 539 & $269-798$ & $293-827$ & 22.37 & 23.22 & 26.99 & 28.96 & 68.74 & 64.29 & 38.19 & 30.75 \\
\hline Harvest index $(\%)$ & 16.8 & 16.92 & $13.64-21.39$ & $14.48-22.30$ & 11.90 & 13.43 & 18.69 & 19.28 & 40.55 & 48.53 & 9.89 & 13.43 \\
\hline $\begin{array}{l}\text { Reaction to } \\
\text { MYMV }\end{array}$ & 3.9 & 4.1 & $1-8$ & $2-8$ & 32.64 & 35.04 & 37.57 & 39.09 & 75.52 & 80.30 & 58.44 & 64.70 \\
\hline $\begin{array}{l}\text { Zinc content } \\
(\mathrm{mg} / \mathrm{kg} \text { seed }) \\
\end{array}$ & 21.68 & 25.69 & $9.8-45.4$ & $11.8-65.4$ & 31.29 & 32.27 & 36.13 & 36.66 & 75.02 & 77.50 & 48.36 & 51.51 \\
\hline $\begin{array}{l}\text { Iron content } \\
\text { (mg/kg seed) }\end{array}$ & 63.65 & 85.82 & $13.8-168.9$ & 25.3-178.4 & 45.58 & 31.90 & 54.52 & 38.33 & 69.87 & 69.27 & 65.53 & 45.52 \\
\hline
\end{tabular}


Table.2 Assortment of mungbean RILs, parents and checks based on micronutrients content and their response to $\mathrm{Zn}$ and Fe application

\begin{tabular}{|c|c|c|c|c|c|c|}
\hline $\begin{array}{l}\text { Micro- } \\
\text { nutrient }\end{array}$ & Category & Response & Genotypes & $\begin{array}{c}\text { Total } \\
\text { genotypes }\end{array}$ & $\begin{array}{l}\text { Total } \\
\text { RILs }\end{array}$ & $\begin{array}{l}\text { Proportion } \\
\text { of RILs } \\
(\%)\end{array}$ \\
\hline \multirow[t]{4}{*}{ Zinc } & \multirow{2}{*}{$\begin{array}{l}\text { Low to } \\
\text { moderate } \\
\text { content in } \\
\text { seeds } \\
(<30 \mathrm{mg} / \mathrm{kg} \\
\text { seed })\end{array}$} & Positive & $\begin{array}{l}\text { RIL-2, 3, 4, 5, 6, 8, 10, 12, 16, 18, 19, 20, 21, } \\
22,24,30,31,32,35,38,45,48,49,52,54, \\
55,60,62,63, \text { MH 2-15, MH 1-25, MH 421, } \\
\text { MH } 318\end{array}$ & \multirow[t]{2}{*}{$\begin{array}{l}63 \text { RILs } \\
1 \text { Parent } \\
3 \text { Checks }\end{array}$} & 29 & 46 \\
\hline & & Neutral & $\begin{array}{l}\text { RIL-7, 9, 13, 14, 15, 17, 23, 25, 26, 27, 28, 29, } \\
33,36,39,40,41,42,43,44,46,47,50,51 \\
53,56,57,58,64,65,66,67,68,69\end{array}$ & & 34 & 54 \\
\hline & \multirow{2}{*}{$\begin{array}{l}\text { High content } \\
\text { in seeds } \\
(>30 \mathrm{mg} / \mathrm{kg} \\
\text { seed })\end{array}$} & Positive & RIL-1, ML 776 & \multirow{2}{*}{$\begin{array}{l}7 \text { RILs } \\
1 \text { Parent }\end{array}$} & 1 & 14 \\
\hline & & Neutral & RIL-11, 34, 37, 59, 61, 70 & & 6 & 86 \\
\hline \multirow[t]{4}{*}{ Iron } & \multirow[t]{2}{*}{$\begin{array}{l}\text { Low to } \\
\text { moderate } \\
\text { content in } \\
\text { seeds } \\
(<100 \mathrm{mg} / \mathrm{kg} \\
\text { seed })\end{array}$} & Positive & $\begin{array}{l}\text { RIL-2, 9, 11, 13, 14, 15, 16, 17, 18, 19, 20, 21, } \\
22,23,24,25,26,27,30,31,35,36,37,39, \\
\text { 43, 44, 45, 56, 57, 58, 59, 60, 61, 62, 63, 64, } \\
65,66,67,68,69,70, \text { MH 2-15, MH 1-25, } \\
\text { MH 421, MH 318 }\end{array}$ & \multirow[t]{2}{*}{$\begin{array}{l}56 \text { RILs } \\
1 \text { Parent } \\
3 \text { Checks }\end{array}$} & 42 & 75 \\
\hline & & Neutral & $\begin{array}{l}\text { RIL-8, 12, 28, 29, 40, 41, 42, 47, 49, 51, 52, } \\
53,54,55\end{array}$ & & 14 & 25 \\
\hline & \multirow{2}{*}{$\begin{array}{l}\text { High content } \\
\text { in seeds } \\
(>100 \mathrm{mg} / \mathrm{kg} \\
\text { seed })\end{array}$} & Positive & RIL-3, 4, 5, 7, 10, 32, 33, 34, ML 776 & \multirow{2}{*}{$\begin{array}{l}14 \text { RILs } \\
1 \text { Parent }\end{array}$} & 8 & 57 \\
\hline & & Neutral & RIL-1, 6, 38, 46, 48, 50 & & 6 & 43 \\
\hline \multirow{2}{*}{\multicolumn{2}{|c|}{ Zine and Iron }} & Positive & $\begin{array}{l}\text { RIL-2, 3, 4, 5, 10, 16, 18, 19, 20, 21, 22, 24, } \\
\text { 30, 31, 32, 35, 45, 60, 62, 63, ML 776, MH 2- } \\
\text { 15, MH 1-25, MH 421, MH } 318\end{array}$ & $\begin{array}{l}20 \text { RILs } \\
2 \text { Parents } \\
3 \text { Checks }\end{array}$ & 20 & 21 \\
\hline & & Neutral & RIL-28, 29, 40, 41, 42, 46, 47, 50, 51, 53 & 10 RILs & 10 & 14 \\
\hline
\end{tabular}


Similar results were reported by Om Vir and Singh (2016) while Gadakh et al., (2013) and Jyothsna and Anuradha (2013) obtained contradictory results. High heritability coupled with high genetic advance but low to moderate GCV estimates were obtained for plant height and number of pods per plant. This unfolded that the above listed traits have lesser variability even then they can be improved through selection. This result is aided by the findings of Dhananjay et al., (2009) and Om Vir and Singh (2016). Further, days to $50 \%$ flowering, days to maturity and 100 -seed weight had high heritability coupled with low genetic advance and low to moderate GCV which were also observed by Om Vir and Singh (2016).

From the above discussions, it can be concluded that number of branches per plant, number of pods per plant and biological yield per plot should be kept in mind while selection is to be practiced for high seed yield. Besides, plant height should also be considered while performing selection for high seed yield. However, some differences are obvious in this respect which may be due to the facts that heritability may differ from crop to crop, cross to cross, location to location, year to year and even in the same year from method to method of heritability estimation.

Among the 70 RILs, some were more responsive to zinc and iron application, some were less and other didn't respond at all (Table 2). About $43 \%$ RILs responded positively to zinc application and about $71 \%$ to iron application and exhibited more than 20 $\%$ increase in their content in seeds under treated environment. Only $29 \%$ RILs responded to the application of both the micronutrients ( $\mathrm{Zn}$ and $\mathrm{Fe}$ ). There were only 10 RILs (about $14 \%$ ) which didn't show any response to either of the micronutrient application. RILs having high zinc (>30 $\mathrm{mg} / \mathrm{kg}$ seed) and high iron (>100 mg/kg seed) contents responded less to the zinc and iron applications as compared to the RILs having low to moderate zinc $(<30 \mathrm{mg} / \mathrm{kg}$ seed) and iron $(<100 \mathrm{mg} / \mathrm{kg}$ seed) content. Only about $14 \%$ of the high zinc content RILs responded positively to zinc application, whereas there were $46 \%$ of low to moderate zinc content RILs which responded positively to zinc application. Similarly, among the high iron content RILs $57 \%$ responded positively to iron application, whereas $75 \%$ of the low to moderate iron content RILs responded positively to iron application. Both the parents and all the checks responded positively to zinc and iron application except for parent ML 776 which didn't respond to only iron application.

Maximum zinc content ( $45.4 \mathrm{mg} / \mathrm{kg}$ seed) was found in RIL-61 followed by RIL-1 (40.5 $\mathrm{mg} / \mathrm{kg}$ seed), RIL-11 (36.4 mg/kg seed), RIL37 (32.9 mg/kg seed) and RIL-59 (32.3 mg/kg seed) and maximum iron content (168.9 $\mathrm{mg} / \mathrm{kg}$ seed) in RIL-1 followed by RIL-3 (125 $\mathrm{mg} / \mathrm{kg}$ seed), RIL-38 (122 mg/kg seed), RIL37 (121 mg/kg seed) and RIL-7 (118 mg/kg seed) under untreated environment. Response to zinc application was observed maximum in RIL-1 (61 \%) among the high zinc content RILs. Likewise, response to iron application was highest in RIL-5 (64\%) among the high iron content RILs. High seed yield per plot was bagged from RIL-25 (125.7 g), RIL-54 (126.3 g), RIL-58 (126.7 g), RIL-60 (123.9 g) and RIL-67 (138.3 g). RIL-1 was observed to have high seed yield (100.5 g per plot) along with high zinc (40.5 mg/kg seed) and iron (168.9 mg/kg seed) content in seeds.

The present study, intended to examine the genotypic variation in yield traits and micronutrients content in mungbean RILs and identification of superior RILs, will be of great use and will serve as a stepping stone in formulation and effective execution of future 
breeding programmes on biofortification in mungbean. To initiate a systematic breeding programme and to develop mungbean varieties with combination of high seed yield and micronutrients ( $\mathrm{Zn}$ and $\mathrm{Fe}$ ) content, the above specified RILs for different traits should be used in crossing programmes.

\section{References}

Anonymous 2016. Project Coordinator's Report, AICRP on MULLaRP (Mungbean \& Urdbean) IIPR, Kanpur.

Arshad, M, Aslam, M and Irshad, M. 2009. Genetic variability and path coefficient character association among morphological traits of mungbean (Vigna radiata L. Wilczek) genotypes. Journal of Agricultural Research, 47: 121-126.

Begum, S, Noor, M, Hassan, G, Rahman, HU, DurrishwarUllah, H and Jan, H. 2012. Genotypic association among yield and related attributes in mungbean genotypes. International Research Journal of Agricultural Science and Soil Science, 2(5): 188-193.

Benton Jones, J. 1989. Plant analysis techniques. Benton-Jones Laboratories, Georgia

Burton, GW and Devane, EH. 1953. Genetic variability and heritability in soybean. Agronomy Journal, 45: 478-481.

Dhananjay, RK, Singh, BN and Singh, G. 2009. Studies on genetic variability, correlations and path coefficients analysis in mungbean. Crop Research, 38(1/3): 176-178.

Gadakh, SS, Dethe, AM and Kathale, MN. 2013. Genetic variability, correlations and path analysis studies on yield and its components in mungbean (Vigna radiata (L.) Wilczek). Bioinfolet, 10(2a): 441-447.

Hanson, CF, Robinson, HF and Comstock, RE. 1956. Biometrical studies on yield in segregating population of Korean Lespedesa. Agronomy Journal, 48: 248272.

Johnson, HF, Robinson, HF and Comstock, RE. 1955. Estimates of genetic and environmental variability in soybean. Agronomy Journal, 47: 314-31.8

Jyothsna, M and Anuradha, CH. 2013. Genetic variability, correlation and path coefficient analysis for yield and yield components in mungbean (Vigna radiata (L.) Wilczek). Journal of Research, ANGRAU 41(3): 31.

Khedar, OP, Singh, RV and Prakash, V. 2006. Variability and characters association among quantitative characters of mungbean. Journal of Arid Legumes, 3(2): 68-70.

Kumar, S and Katiyar, M. 2015. Genetic variability, heritability, expected genetic advance and character association in mungbean (Vigna radiata (L.) Wilczek). International Journal of Advanced Research, 3(5): 1371-1375.

Niharika, B, Singh, DP and Khulbe, RK. 2014. Genetic variability and correlation studies in advance interspecific and inter-varietal lines and cultivars of mungbean (Vigna radiata). Journal of Food Legumes, 27(2): 155157.

Omvir and Singh, AK. 2016. Analysis of morphological characters interrelationships in the germplasm of mungbean (Vigna radiata (L.) Wilczek) in the hot arid climate. Legume Research, 39(1): 14-19.

Prakash, V and Shekhawat, US. 2012. Analysis of genetic diversity in newly developed genotypes of mungbean (Vigna radiata (L.) Wilczek). Journal of Progressive Agriculture, 3(2): 47-50.

Rathor, P, Singh, A, Imran, M, Ali, K and Fatma, R. 2015. Analysis of genetic variability for some quantitative traits in mungbean (Vigna radiata (L.) 
Wilczek). Indian Research Journal of Genetics and Biotechnology, 7(1): 148151.

Raturi, A, Singh, SK, Sharma, V and Pathak, R. 2015. Genetic variability, heritability, genetic advance and path analysis in mungbean (Vigna radiata (L.) Wilczek). Legume Research, 38(2): 157-163.

Reddy, DKR, Venkateswarlu, O, Obaiah, MC and Jyothi, GLS. 2011. Studies on genetic variability, character association and path co-efficient analysis in greengram (Vigna radiata (L.) Wilczek). Legume Research, 34(3): 202-206.

Samreen, T, Humaira Shah, HU, Ullah, S and Javid, M. 2013. Zinc effect on growth rate, chlorophyll, protein and mineral contents of hydroponically grown mungbean plants (Vigna radiata). Arabian Journal of Chemistry, 52: 2115-2126.

Shivasubramanian, S and Menon, N. 1973. Heterosis and inbreeding depression in rice. Madras Agriculture Journal, 60: 1139-1144.

Singh, CM, Mishra, SB, Pandey, A and Arya, M. 2014. Environmental influence on heritability and selection response of some important quantitative traits in green gram (Vigna radiata (L.)
Wilczek). Journal of Food Legumes, 27(2): 95-98.

Singh, V, Yadav, RK, Yadav, R, Malik, RS, Yadav, NR and Singh, J. 2013. Stability analysis in mungbean (Vigna radiata (L.) Wilczek) for nutritional quality and seed yield. Legume Research, 36(1): 5661.

Suresh, S, Jebaraj, S, Hepziba, S and Theradimani, M. 2010. Genetic studies in mungbean (Vigna radiata (L). Wilczek). Journal of Plant Breeding, 1(6): 1480-1482.

Tabasum, A, Saleem, M and Aziz, I. 2010. Genetic variability, trait association and path analysis of yield and yield components in mungbean (Vigna radiata (L.) Wilczek). Pakistan Journal of Botany, 42(6): 3915-3924.

Taunk, J, Yadav, NR, Yadav, RC and Kumar, R. 2012. Genetic diversity among green gram (Vigna radiata (L.) Wilczek) genotypes varying in micronutrient $(\mathrm{Fe}$ and $\mathrm{Zn}$ ) content using RAPD markers. Indian Journal of Biotechnology, 11: 48-53.

Tiwari, A, Mishra, SP and Nag, SK. 2014. Correlation and path coefficient analysis for seed yield and its components in mungbean (Vigna radiata). Trends in Biosciences, 7(1): 42-45.

\section{How to cite this article:}

Kritika, Rajesh Yadav, Sunayana and Ravika. 2018. Evaluation of Genetic Variability and Identification of Micronutrients Rich Recombinant Inbred Lines in Mungbean (Vigna radiata (L.) Wilczek). Int.J.Curr.Microbiol.App.Sci. 7(06): 756-764. doi: https://doi.org/10.20546/ijcmas.2018.706.088 